Прегледни чланак

$349.41(439)$

Csilla Csák, Ph.D., Assistant Professor

Faculty of Law Miskolc

Zoltán Nagy, Ph.D., Assistant Professor

Faculty of Law Miskolc

\title{
Regulation of Obligation of Use Regarding the Agricultural Land in Hungary
}

Abstract: In this paper regulation issues of use, including mainly issues of the lease in Hungary are presented (barriers and financial issues of the use obligations). Basic regulation regarding the consensual nature of land use is the Code Civil. Compared to it special regulation can be found in the Act on arable land. There is more specialization regarding each branch of cultivation, such as the act on forest, grape cultivation, lands under nature protection.

Hungary joined the EU in 2004. During this accession the legal regulation regarding arable land must have been considered by the obligation of harmonisation. Accordingly, property and use relationships of the Members States' citizens were altered. Moratorium was given to foreign citizens till 2014, i.e. there is a possibility for different regulation regarding foreigners.

There have recently been amendments of the Act on arable land and a process aiming new Act on arable land is at issue. There is a need for amendment mainly because of foreign property acquiring. However issues of property and use are closed, accordingly the amendment of use relations is also due soon. It is urged by the expiry of the moratorium and by the agricultural support issues.

Key words: arable land, land lease, taxation

Before the transformation of regime (1989) the use of agricultural land ${ }^{1}$ was carried out on state farms and in cooperatives within the cooperative com-

${ }^{1}$ Agricultural land: situated in the exterior zone of the settlement and in the land registry it is classified as arable land, grape, orchard, garden, pasture-land, meadow, reed, forest, cultivated area or registered as fishpond. 
mon land use. This model was created in accordance with the economical aims of the large-scale agricultural cultivation. Furthermore, the individual land use of private persons was made possible by croft land use or garden-plot land use.

The transformation of regime basically annulled the large-scale collective land use and by expanding the private property it legalized the proprietary use. Therefore, if a cooperative wish to use an agricultural land, it shall conclude an agreement with the land proprietor. ${ }^{2}$ If the proprietor does not allow other persons to use his/her land, he/she has to take care of the land cultivation. It means that the land productivity maintenance and the use according to agricultural classification (grape, orchard, forest) should be taken into consideration.

Actually the use is in connection with the proprietary issues regarding that the proprietor uses his/her land on its own or transfers it. By use transferring it is crucial question to determine the way of use.

Since 1th May, 2004 Hungary is a member of the European Union. With the accession a new chapter has begun regarding the Hungarian legal regulation, because the Union's legislation makes a great impact on the Hungarian regulation. It means on the one hand the obligation of harmonization according to the accession negotiations and the documents; on the other hand after the accession the already harmonized legislation.

\section{Basis of the legal regulation of land use}

By the regulation of land regarding the branch of law the distinction between the private and public sector's regulation could be found. Civil law emerges regarding the substantive law and obligation; administrative regulation can be discerned in the administrative actions. Nonetheless, teaching of and doing research on the land as special regulations belong to the agrarian law. Agrarian law deals with - among others - subjective and objective side of the agrarian plant structure, and the agrarian finance (subvention, credits). Land protection refers to environment protection, but taxation of the agricultural activity belongs to financial law.

According to the consensual nature of the land use obligations the basic regulation can be found in the Civil $\mathrm{Code}^{3}$ (regarding the Hungarian abbreviation furthermore "Ptk."). In comparison with Ptk. the Act on the agricultural land (regarding the Hungarian abbreviation furthermore "Tft.") contains special rules. ${ }^{4}$ Moreover, regarding each classification there are specialized rules. For

${ }^{2}$ It must be mentioned, that according to the Act on cooperatives it is possible to prescribe land transport in the constitution as a condition of the membership in the cooperative. Nowadays, it is a possibility; it depends on the members' decision.

${ }^{3}$ Act IV. of 1959. In the meantime the new Ptk. has been adopted (Act CXX of 2009), which comes into force from 1st of May continuously.

${ }^{4}$ Act LV. of 1994 
example this relates to the acts on forest, grape cultivation, and territories under environment protection.

Within the agricultural production land lease has an outstanding meaning. According to the lease contract the leaseholder is entitled alongside with remuneration for the temporary use, practice of the land or other profitoriented matter. The rules of lease shall apply to the land lease with regard to the special rules. Lease is a general contract, land lease is a special one. Lease means use; land lease means more than use, which refers to the fact that the object of land lease shall be fruitful. It must be appropriate to guarantee the option of use of profits. ${ }^{5}$ The land lease contract shall be concluded in written from. Without the written form the consequences of invalidity shall apply.

According to Ptk. the land sub-lease is invalid, except the Act makes it possible. Tft. makes it possible by special circumstances and exclusively in order to reach the production integration.

The leaseholder having the leaser's consent may agree with other land user on the transfer of land for a definite time. This agreement shall be concluded written. This transfer does not concern the obligations of the leaseholder towards the leaser - if the parties do not agree otherwise. ${ }^{6}$ The amendment of $\mathrm{Tft}$. of 2002 made possible to transport the lands of the leaseholder into cooperation which procure and sale and into other associations. ${ }^{7}$ This legal method may guarantee the use of farmlands, or as it called in Hungary the family farms. . According to the Act family farms include the property of lands of maximum 300 ha (including the interior zone land under agricultural and forestry cultivation); or include lease or use of all agricultural lands of maximum 300 ha of a farmer family with the usage of the belonging immovable and movable (building, edifice, agricultural facilities, equipment, machine, animals and assortment etc.) being registered in the inventory, the farming is based upon the full employment of at least one family member and on the cooperation of the other family members. ${ }^{9}$.

${ }^{5}$ PRUGBERGER, Tamás: A haszonbérleti szerződésről de lege lata és de lege ferenda (About the land lease contract de lege lata and de lege ferenda). In: Publicationes Universitatis Miskolcinensis Sectio Juridica et Politica TOMUS XXII. Miskolc University Press 2004. 463.p.

${ }^{6}$ Tft. $\S 12 / \mathrm{A}$.

${ }^{7}$ OLAJOS, István: Termőföldek használatának speciális szabályai. (Special rules of land use) In: CSÁK (ed.): Agrárjog (Agrarian Law), Novotni, Miskolc, 2008. 125.p.

${ }^{8}$ OLAJOS, István-PRUGBERGER, Tamás: A termőföld birtoklás, hasznosítás és forgalmazás a családi gazdaság elősegítésének új jogi szabályozása tükrében.(The land’s asset, use and transfer in the light of the new legal regulation supporting family farms). Magyar Jog (Hungarian Law) 5/2002, 286-295.p.

${ }^{9}$ Tft. $\S 3 \mathrm{~h}$. 


\section{Legal forms of land use}

Special rules are applicable to the land lease in comparison with lease of other objects or a right. This specialty can be discerned firstly in the size of lands appropriate for lease, secondly in the land lease's duration, thirdly in the regulation of the right for pre-lease, fourthly in the installation of the land lease registry, fifthly in the cessation of the lease. These rules are declared in Tft. Act on the agricultural land.

The inland private and legal person, or associations without legal personality can lease lands of at the most 300 ha or 6000 golden crowns. This rule shall apply to foreigners too. This means the main rule, under which there are of course exceptions, because the Hungarian State, the local government can lease without any limitation, association and cooperation are allowed to lease lands of at maximum 2500 ha or 50.000 golden crowns. Under this limitation that land should not be taken into consideration which is leased from the member of cooperation, association, from proprietor of personal share or from the National Land Fund. The Hungarian regulation similar to other Western-European countries' regulation limits the size of lands being leased, but does not determine a lower bound rather an upper bound. ${ }^{10}$ This kind of regulation might be reasonable, but it has some deficiencies, like lease is not bound to the proficiency of the lease holder, to verification of the agricultural vocation, or to the agricultural experience.

The land lease contract can be concluded for a definite time, of which duration might be maximum 20 years. It is not prohibited to conclude the contract again for a definite time. This rule shall apply to inlanders and foreigners (private or legal person) as well. Of course, there are exceptions regarding the classification. If the land lease contract refers to forest or forest cultivation classification, it might be concluded for 5 years after the expiration of the production period (cutting age). If the land lease contract refers to grape or orchard classification, it might be concluded till the end of the year during which the grape, orchard or plantation are worth (period of depreciation). This kind of land lease contract can not be terminated by dismissal, but each part has right for termination without notice, if the conditions are met. For example the leaser might terminate the contract, if the lease holder transferred the land use without the leaser's consent or not in accordance with it, if he/she made an investment on the land overstepping the fair farming; or he/she changed the classification of the land; or carried out actions not being in accordance with the environment protection rules or the prescriptions of the authorities and they affect unfavora-

${ }^{10}$ OLAJOS, István: A termőföldröl szóló törvény módosítása avagy mi fér bele száz napba. (Amendment of the Act on agricultural land. What can be done during 100 days?) Napi Jogász (Daily Lawyer) 7-8/200, 8-12.p. 
bly the state of the environment; or endangered anyhow the maintenance of the natural merits. The private lease holder might terminate the contract without any notice, if his/her state of health is getting such worth, or there is a such longlasting change in his/her family- or life circumstances, which hinder the fulfillment of his/her obligations under the contract.

There is a right for pre-emption or pre-lease in the case of sale or transfer of use of the land. The right for pre-lease entitling the lease holder is in common with the right for pre-emption; therefore, if there is a gap in the regulation, the rules of the right for pre-emption shall apply. ${ }^{11}$ By practicing the right for preemption Tft. declares a hierarchy. Therefore the earlier lease holders are in favor at the first place with those who made a plantation or operate a fishpond or animal farm. Then the neighbours, and other inhabitants are next in line, who carry out professional agricultural activity. If there are more offers on behalf of the authorized at the same place in the hierarchy, the leaser might decide, with whom he/she is going to conclude the contract. ${ }^{12}$

There is a great number of entitled for pre-lease right; therefore, the notification of the entitled arose as a big issue. In this case the notification of each entitled by the lease holder cannot be applicable. Therefore, the offer should be published by the local government or on the government portal for a period of time. The entitled can make a valid declaration to offers published in this way.

This right for pre-lease shall not apply to close relatives in the case of land lease contract, and of land lease being condition for the farm transmission subsidy or in the case of garden-plot (small exterior zone parcel).

There are two types of land lease relationship in Hungary: part tenancy and partial cultivation.

According to the part tenancy contract the leaser is entitled for use and collection of fruits of a land for a definite time, and in return is obliged to transfer the half or other part of the product to the lease holder in kind. The rules of land lease shall apply to the part tenancy except for the duration of the contract and size of the leasable land.

In the case of partial cultivation the parties together determine what kind of corps would be cultivated on the land, what kind of obligations may arise from the contract regarding the parties (ground-clearance, plough, seeding, cutting, plant-care, plant-protection, harvest), the amount of the share; and the

${ }^{11}$ LESZKOVEN, László: A termőföldet érintő elővásárlási jog egyes kérdései. (Some issues of the right for pre-emption on agricultural land.) In: Publicationes Universitatis Miskolcinensis Sectio Juridica et Politica TOMUS XXII. Miskolc University Press 2004. 396.p.

12 OLAJOS, István: A 2002. február 22-én hatályba lépő termőföld elővásárlási és előhaszonbérleti jogok gyakorlásáról. (About the practice of rights for pre-emption and pre-lease on the agricultural land coming into force on $22^{\text {nd }}$ of February, 2002.) Napi Jogász (Daily Lawyer), 4/2002, 4. 7-12.p. 
rules of carrying the damage in the case of vis maior or extraordinary events. The rules of land lease shall apply to the partial cultivation except for the duration of the contract and size of the leasable land.

The cultivation of land might be carried out according to the right for usufruct and use. In the case of usufruct the entitled can use and collect of the fruits of an object being of someone else's property.

According to the right for use the entitled uses and collects the fruits of an object not overstepping the needs of the co-living family members. These two legal institutions have been regulated in the Civil Code (Ptk.). Both are appropriate to create right for use on the land either by contract or by authority's action. This latest is not limited by the Tft., but the rights arising from a contract are narrowed. The aim was not to avoid the rules of usufruct on land. The land in the property of the party and the lands falling under usufruct (use) should be reckoned up and the statutory land maximum shall be taken into consideration in accordance with it.

The restrictive rules of the property transfer shall apply to the foundation of right for usufruct and use by contract. Therefore, foreigner (except for citizens of the Member States) cannot be subject of such contract.

Under this rule there is an exception: land use by courtesy, by which the close relative can gain the land use free of charge.

In Hungary till the Accession (2004) foreigners could not gain land. After this alongside strict conditions ${ }^{13}$ the citizens of the Member States can, but other foreigners cannot. Most of the time this restriction was avoided by use obligations, by which the foreigner gained the asset and by means of a contractual declaration stated the possibility of property transfer, if the legal environment in the future does not restrict the property transfer of foreigners. The amendment of Tft. introduced the land use registry, which aims to make visible these kinds of efforts and is condition for the recourse of agrarian subventions. It was created for the reliable verification of land use, which is a credible registry supervised by an authority and registers any kind of title regarding land use. ${ }^{14}$.

${ }^{13}$ Member State's citizen: citizen of the European Union's Member State, of a state belonging to the European Economic Area, or according to the international treaty citizen of a State falling under the same recognition with the above mentioned States. The rules applicable to the inland private persons shall apply to those Member State's citizens, who wish to settle down as farmer performing independent agricultural activity and have been living and performing this activity in Hungary continuously, legally at least for 3 years.

14 SZILÁGYI, János Ede: A termőföldek törvényes elővásárlási jogának alakulásáról, különös tekintettel a rendszerváltás utáni jogfejlödésre. (About the statutory right for pre-emption on land with special regard to the development after the transformation of regime.) In: Publicationes Universitatis Miskolcinensis Sectio Juridica et Politica TOMUS XXIV. Miskolc University Press 2006. 520.p. 


\section{Taxation rules of land lease}

The agricultural activity and the taxpayers carrying out such activity play an important issue in taxation regulation.

Generally speaking, all taxation regulation endeavors to create an ordinary regulation and to validate the neutrality in competition. Besides, the legislator prefers those taxpayers who perform agricultural activity. ${ }^{15}$

The legislator takes it into consideration, that this branch has a great expenses demand, and receipts do not always prove these expenses (own workforce offered, own stocks used). The most of taxpayers perform this activity complimentary, that is why the income is lower, the sector has a great need of assets and workforce, and the investments clear the costs on the long run. For the state agriculture is a favorably treated, strategic branch, therefore, not only the activity but the taxpayers also can not be burdened with high taxes.

Considering all the facts, tax law tries to bring this branch in a favorable position with its own measures. Such measures are:

(a) special taxation forms and guarantee of legal position for some taxpayers;

(b) to ensure the special taxation of agricultural products and of the agricultural activity;

(c) determination of special tax rates;

(d) assurance of freedom taxation;

(e) prescription of reduction of tax base;

(f) assurance of tax credits.

In the case of land lease there is a similar regulation, though tax law deals with this institution only narrowly. Special rules can be found in the Personal Income Tax and Value Added Tax law (VAT). ${ }^{16}$

Vat law deals with the issues of lease - and not only with the land lease by the rules of taxation freedom. The Act contains different rules to taxpayers performing agricultural activity, but there is not any construction regarding lease. ${ }^{17}$

Although among the tax free categories there are rules regarding the rental and lease of real estate. ${ }^{18}$

The Act on VAT determines two types of tax free category: taxation freedom without tax deduction (activities with public interest, financial, insurance

${ }^{15}$ NAGY, Zoltán: Az agrárszektor különleges adójogi szabályozásának alapkérdései. (Basic Issues of the special taxation rules of the agrarian sector.) In: CSÁK, Csilla (ed.): Agrárjog (Agrarian Lae), Novotni,, Miskolc, 2008. 306. p.

${ }^{16}$ Act CXVI of 1995 on the personal income tax, Act CXXVII of 2007on VAT

${ }^{17}$ HADI, László (ed.): Az új adójog magyarázata, (Interpretation $\mathrm{f}$ the new Tax law) 2010. HVG-ORAC Kft., Budapest, 557-559. p.

${ }^{18}$ Act on VAT $\S 86$. (1) 1 . 
services etc.); and taxation freedom with tax deduction (sale of goods within the EC, activity connected to the international transport). ${ }^{19}$

Lease belongs to the taxation freedom without tax deduction, which is favorable, firstly, tax does not need to be counted upon, and secondly therefore there is not any tax obligation on lease. But it is disadvantageous on behalf of the tax payers, because the tax transferred to them cannot be deducted.

The Act on Personal Income Tax regulates land lease in more details by defining the legal institution. According to tax law, it concludes land lease, if the private proprietor or the beneficiary of usufruct lease the land according to a written agreement for one or more year in return of fee for usage of agriculture, forestry and fishery. ${ }^{20}$

Rental of the real estate (including land lease) falls under a special regulation according to the personal income taxation. The taxpayer has options after which income group he/she wishes to classify his/her rental or lease activity; and tax pay takes place according to this classification. ${ }^{21}$

If the taxpayer chooses to rank his lease activity into the composite taxation income, the taxpayer has the possibility for itemized cost accounting, or to account cost proportion determined in the statue. ${ }^{22}$ After the deduction the remainder amount will be the income, which shall be part of the composite tax base. ${ }^{23}$

If the Act makes it possible, the taxpayer can rank his income under lease activity into the separate taxation income. In this case there is no possibility for cost accounting, but there is a lower tax key in the Act (25\%) regardless the amount of the income. ${ }^{24}$

The Act supports long-lasting land lease contracts by means of special tax free regulations. The income deriving from land lease is tax free, if the land

${ }^{19}$ HADI (2010.): op. cit. 507-530. p.

${ }^{20}$ Act on Personal Income Tax §3. 53. tax law handles the definition of lease within a wider taxation category, ie. the rental of real estate.

${ }^{21}$ SZAKÁCS Imre: Az adózás nagy kézikönyve (Great handbook of Taxation), Complex Kft., Budapest, 2008. 761-762. p. Income has two main types from the taxation's point of view: composite income and separate income. By composite income the tax bases should be contracted, this amount shall be ranked in the tax table's zones, after that the counted tax shall be determined by means of the tax table. (Zone progressive taxation). The counted tax is deducted by the tax credits. The tax base of separate income and the taxation shall be determined by the types of the income.

${ }^{22}$ Act on Personal Income Tax $\S 18$ (1) In this case the lease income belongs to the incomes deriving from independent activity within the composite income.

${ }^{23}$ Act on Personal Income Tax $\S 30$ According to the regulation in 2010 in the case of composite income the tax rate will be $17 \%$ under the tax base of 5 Million forint; above 5 Million forint, the amount over exceeding 5 Million forint will be taxed by $32 \%$.

${ }^{24}$ Act on Personal Income Tax $\S 74$. There is an exception: the taxpayer performs lease as individual entrepreneur. In that case the taxation rules of individual entrepreneurs shall apply. 
lease contract is concluded for five years. But, if the contract being tax free terminates within the tax break period, the taxpayer is obliged to pay taxes with default interest. (This freedom taxation is not concerned, if the termination is caused by vis maior, or by termination without notice.)

\section{The agricultural land in the light of the EC}

Regarding the Community regulation there are rules concerning land policy, but basically the national, Member State's regulation shall apply. The Community's primary legislation relates to land policy issues in the field of freedom of goods, prohibition of discrimination and the right for settlement. There is a general prohibition, ie. discriminative legislation between EU and non EU Member State's citizens should not be essentially unfavorably distinctive. These principles can be discerned in the secondary legislation of the Community and in the judicial practice of the European Court of Justice.

The European Community and Hungary concluded the European Agreement in 1991. This document referred to land property regarding the freedom of settlement as determining the time till Hungary must assure the national treatment with regard to the community corporations and citizens. Regarding use relationships the principle of national treatment has been already applied.

With respect to the property issues Hungary managed to gain a moratorium $(7+3$ years) regarding the regulation of property transfer of EU citizens. It might be reasonable because of the low land prices. These seven years will expire in 2011. Concerning the remained 3 years Hungary handed in a petition to the Union. If this petition is accepted, Hungary shall assure this principle in 2014 regarding the property transfer of EU citizens.

Currently, according to this process the Act on agricultural land needs to be amended. This has already begun. The amendment is needed first of all because of the foreigners' property transfer. But, the issues of property and use belong to each other; therefore, the amendment of the use relationships will also take place. These issues are urged not only by expiry of the moratorium, but also by the agrarian subsidies. 
Др Чила Чак, доченим

Правног факулиетета у Мишколиу

Др Золиман Нађ, доченей

Правног факулиеети у Мишколиу

\section{Права употребе пољопривредног земљишта у Мађарској}

\section{Сажейик}

У раду се даје приказ питања у вези са правима употребе пољопривредног земљишта у Мађарској, пре свега правима која проистичу из уговора о закупу, с посебним освртом на њихова ограничења, финансијски аспект итд.

Имајући у виду консенсуални карактер облигационих права употребе пољопривредног земљишта, њихов општи правни оквир је садржан у одредбама Грађанског законика. Посебне одредбе о овим питањима се налазе у Закону о пољопривредном земљишту, као и у прописима којима су уређене поједине области пољопривреде, као што су прописи о заштити шума, виноградарству, прописи којима је уређена заштита животне средине у специјалним резерватима природе итд.

Године 2004. Мађарска је постала чланица Европске уније. У процесу придруживања је требало извршити хармонизацију домаћег права са комунитарним правилима и у погледу правног уређења пољопривредног земљишта. При томе је било неопходно изменити правила о могућности стицања права својине на пољопривредном земљишту и права његове употребе од стране држављана осталих чланица Уније. Мађарска је до 2014. године добила тзв. мораторијум, тј. право да различито уреди наведена права, зависно од тога да ли је њихов титулар држављанин Мађарске или држављанин неке од држава чланица Уније.

Тренутно је у Мађарској веома актуелно питање измене Закона о пољопривредном земљишту или усвајање новог закона. Измене овог закона намеће, пре свега, потреба да се уреди право страних лица на стицање пољопривредног земљишта. Право својине на пољопривредном земљишту и права употребе истог су у тесној вези, те се основано могу очекивати измене и правила која се односе на употребу пољопривредног земљишта. Потребу за измену правног уређења права употребе пољопривредног земљишта актуализује делом и очекивани престанак важења мораторијума 2014. године, делом и посебна питања у вези са субвенцијама пољопривредној производњи.

Кључне речи: пољопривредно земљиште, закуп пољопривредног земљишта, опорезивање 